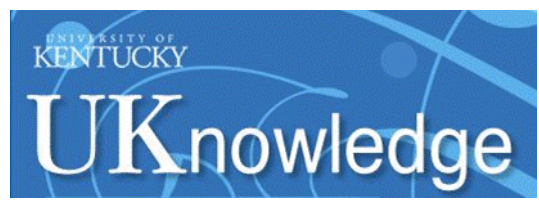

University of Kentucky

UKnowledge

5-1995

\title{
Fecal Bacteria in Agricultural Waters of the Bluegrass Region of Kentucky
}

\author{
J. M. Howell \\ University of Kentucky \\ Mark S. Coyne \\ University of Kentucky, mark.coyne@uky.edu \\ P. L. Cornelius \\ University of Kentucky
}

Follow this and additional works at: https://uknowledge.uky.edu/pss_facpub

Part of the Environmental Microbiology and Microbial Ecology Commons, and the Plant Sciences

Commons

Right click to open a feedback form in a new tab to let us know how this document benefits you.

\section{Repository Citation}

Howell, J. M.; Coyne, Mark S.; and Cornelius, P. L., "Fecal Bacteria in Agricultural Waters of the Bluegrass Region of Kentucky" (1995). Plant and Soil Sciences Faculty Publications. 15.

https://uknowledge.uky.edu/pss_facpub/15

This Article is brought to you for free and open access by the Plant and Soil Sciences at UKnowledge. It has been accepted for inclusion in Plant and Soil Sciences Faculty Publications by an authorized administrator of UKnowledge. For more information, please contact UKnowledge@lsv.uky.edu. 
Fecal Bacteria in Agricultural Waters of the Bluegrass Region of Kentucky

Digital Object Identifier (DOI)

http://dx.doi.org/10.2134/jeq1995.00472425002400030003x

Notes/Citation Information

Published in Journal of Environmental Quality, v. 24, no. 3, p. 411-419.

The copyright holder has granted the permission for posting the article here. 


\title{
TECHNICAL REPORTS
}

\section{Water Quality}

\section{Fecal Bacteria in Agricultural Waters of the Bluegrass Region of Kentucky}

\author{
J. M. Howell, M. S. Coyne, ${ }^{*}$ and P. Cornelius
}

\begin{abstract}
Agricultural runoff influenced by nonpoint pollution frequently exceeds the USEPA standards for bacterial contamination of primary contact water ( 200 fecal coliforms $/ 100 \mathrm{~mL}$ ). Few studies have evaluated the effect of cattle (Bos taurus) grazing on fecal contamination of groundwater in the karst topography of central Kentucky. Our objectives were to: (i) observe the extent and pattern of fecal bacteria in agricultural waters from two central Kentucky watersheds; (ii) determine if monthly sampling accurately assessed the extent and variability of fecal contamination; and (iii) assess the fecal coliform/ fecal streptococci ratio (FC/FS) as an indicator of fecal bacteria source. Springs, streams, and wells in two agricultural watersheds typical of central Kentucky were monitored for fecal coliform and fecal streptococci from December 1991 to January 1993. Springs and wells exceeded primary contact water standards, between 28 and $74 \%$ of the time; streams exceeded water quality standards between 87 and $100 \%$ of the time. When fecal bacteria were present, rainfall rapidly moved them from the soil surface into spring and well water. At two springs in Fleming county, only $29 \%$ of samples exceeded primary contact standards before cattle were present; $80 \%$ exceeded standards after cattle began grazing the surrounding pasture. Monthly sampling adequately reflected the extent of fecal contamination in our study, which had relatively continuous cattle grazing. Although the FC/FS ratio identified domestic animal contamination sources, it did not distinguish between domestic animal and human sources of contamination.
\end{abstract}

$\mathrm{G}$ ROUNDWATER POLLUTION is an understandable concern for rural Americans. Ninety-five percent of rural residents in the USA who supply their own water

Department of Agronomy, Univ. of Kentucky, Lexington, KY 405460091. Contribution of the Dep. of Agron., Univ. of Kentucky. Published as paper 94-3-56 with approval of the Director of the Kentucky Agric. Exp. Stn., Lexington. Received 23 May 1994. *Corresponding author (mscoyn00@ukcc.uky.edu).

Published in J. Environ. Qual. 24:411-419 (1995). rely on groundwater as their primary source (Ilvento et al., 1992). Agricultural practices that promote nonpointsource pollution are a growing issue in rural areas. One pollution source is fecal contamination from domestic cattle (Bos taurus). Numerous studies show that agricultural runoff from pastures contains fecal bacteria concentrations, which frequently exceed the USEPA standard for primary contact water (200 fecal coliform/100 mL) (Doran and Linn, 1979; Jawson et al., 1982; Kunkle, 1970; Niemi and Niemi, 1991; Stephenson and Street, 1978).

Watershed characteristics, land use management, and the proximity of domestic animals to streams play an important role in the severity of fecal contamination (Tiedemann et al., 1988). Cattle grazing increases fecal coliform in agricultural runoff compared with background fecal coliform levels (Dixon et al., 1977; Doran and Linn, 1979; Gary et al., 1983; Stephenson and Street, 1978; Tiedemann et al., 1988). When cattle are allowed to graze directly adjacent to streams, stream banks and bottoms became significant bacterial reservoirs (Kunkle, 1970).

Several studies have been done on pastoral cattle grazing as a nonpoint source of pollution in the western USA (Doran and Linn, 1979; Jawson et al., 1982; Tiedemann et al., 1988). However these studies focused on stream, not groundwater contamination, and do not adequately represent the geological conditions and cattle management systems in the southeastern USA. Subsurface transport of bacteria to shallow springs and wells is a concern in karst areas where groundwater is utilized as a drinking water source. Our first objective was to observe the extent and pattern of fecal bacteria contamination in

Abbreviations: FC/FS, fecal coliform/fecal streptococci ratio; MUG 4-methylumbelliferyl- $\beta$-D-glucuronide; CFU, colony forming unit. 
springs, streams, and wells of two typical agricultural watersheds in the Bluegrass region of Kentucky and determine how often these agricultural waters exceeded USEPA standards for minimum contact or swimming water.

Economical and reliable water quality assessments are essential for effective water quality management (Cotter, 1985). Monthly sampling, while cost effective, may not reflect water quality variation due to water flow dynamics (Thomas et al., 1992). Fecal contamination of agricultural waters reflects complex interactions affecting the survival, infiltration, and movement of enteric organisms in soil, water, and sediment. Since these interactions are dynamic, fecal bacteria concentrations can vary dramatically with time at any given site. Diffuse loading of fecal contamination causes wide variations in fecal bacteria concentrations (Niemi and Niemi, 1990). Davis et al. (1977) suggested that one sample taken on a monthly basis may not represent water conditions throughout the period before subsequent samples are taken. Our second objective was to determine if monthly sampling of agricultural waters accurately assessed the extent and variability of fecal contamination.

Rural agricultural waters receive three principle sources of fecal bacteria: human, domestic animal, and wild animal. To properly assess fecal contamination of a site, it is necessary to identify the contamination source. Geldreich (1976) suggested that the fecal coliform/fecal streptococci ratio (FC/FS) could be used to differentiate between contamination from human (FC/FS $>4$ ), domestic animal (FC/FS between 0.1 and 0.6 ), and wild animal (FC/FS < 0.1) sources. Mean FC/FS ratio has been used to characterize some sites (Doran and Linn, 1979; Jawson et al., 1982). The frequency of FC/FS ratios representative of each contamination source has also been used (Tiedemann et al., 1988). Doran and Linn (1979) indicated that the $\mathrm{FC} / \mathrm{FS}$ ratio is useful in distinguishing between domestic animal and wild animal sources of contamination, but its usefulness in differentiating between human and nonhuman sources of contamination is questionable. Our third objective was to determine whether the FC/FS ratio could be used to identify sources of fecal contamination in agricultural springs, streams, and wells.

\section{DESCRIPTION OF STUDY SITES}

This research was done on two watersheds located in central Kentucky, one in Bourbon County and one in Fleming County. These sites reflect agricultural systems common to central Kentucky. Land use is intermixed grain, hay, and tobacco (Nicotiana tabacum L.) croprazed pastures, feedlots, dairy lots, and forested The soils of both counties are common to central Kentucky. They are deep, well drained soils on undulating broad ridgetops and moderately deep or shallow, well-drained soils on hilly uplands, formed in residuum from limestone or interbedded shale and limestone (G.W. Thomas and J. Haszler, 1994, personal communication).

\section{Bourbon County}

The geology of Bourbon County, interbedded limestone and shale or limestone with karst topography, is typical of the inner Bluegrass region of Kentucky. The Bourbon County watershed is dominated by Lowell (fine, mixed, mesic Typic Hapludalf), Maury (fine, mixed, mesic Typic Paleudalf), and McAfee (fine, mixed, mesic Mollic Hapludalf) silt loam soils. Soil depth to bedrock ranges from 51 to $102 \mathrm{~cm}$ for the McAfee soil and 152 to $305 \mathrm{~cm}$ for the Maury soil (Richardson et al., 1982). Water samples were taken from four springs and two streams on a beef farm (Fig. 1). Throughout the sampling period, Bourbon County water temperatures fluctuated between 8.3 and $14.2^{\circ} \mathrm{C}$ for springs and between 5.4 and $25.1^{\circ} \mathrm{C}$ for streams.

In 1992, the Bourbon County watershed was approximately 583 ha with $2 \%$ of the land in tobacco, $15 \%$ in corn (Zea mays L.), 4\% in soybean [Glycine max (L.) Merr.], and $79 \%$ in hay-pasture. Approximately 400 beef cattle were managed at a stocking rate of one head per hectare. Table 1 shows the land use for each site in Bourbon and Fleming County (G.W. Thomas and J. Haszler, 1994, personal communication). The Bourbon County farm is representative of typical beef cattle management in the Bluegrass region of Kentucky. Pastures are intensively grazed, then left to fallow for varying periods. In the winter, hay is fed to cattle in some pastures, which concentrates cattle in small areas. Cattle were present at least once on all sites during the study, except at Spring B2, which was located below a house.

\section{Fleming County}

The geology of Fleming County, interbedded shale and limestone with some karst topography, is common to the outer Bluegrass region of Kentucky. The Fleming County watershed is dominated by Faywood (fine, mixed, mesic Typic Hapludalf) and Lowell silt loams, and Cynthiana (clayey, mixed, mesic Lithic Hapludalf) silty clay loam soils. Soil depth to bedrock ranges from 25 to $51 \mathrm{~cm}$ for the Cynthiana soil and 102 to $183 \mathrm{~cm}$ for the Lowell soil (Jacobs, 1994). Water samples were taken from two springs, two wells, and one stream at a dairy farm in Fleming County (Fig. 2). Throughout the sampling period, Fleming County water temperatures fluctuated between 8.5 and $14.9^{\circ} \mathrm{C}$ for springs and wells, and between 3.9 and $25.1^{\circ} \mathrm{C}$ for streams.

In 1992, the Fleming County watershed was approximately 145 ha with $5.5 \%$ of the land used for tobacco, $84.5 \%$ in hay-pasture, and $10 \%$ in woods and miscellaneous use (Table 1). The Fleming County watershed contained approximately 50 beef cattle and 85 dairy cattle. A dairy parlor and feedlot were adjacent to Wells F5 and F4, and Stream F3. Springs F1 and F2 were located at the top of the watershed in a pasture above the dairy farm. Cattle were moved on and off the pasture throughout the study. 


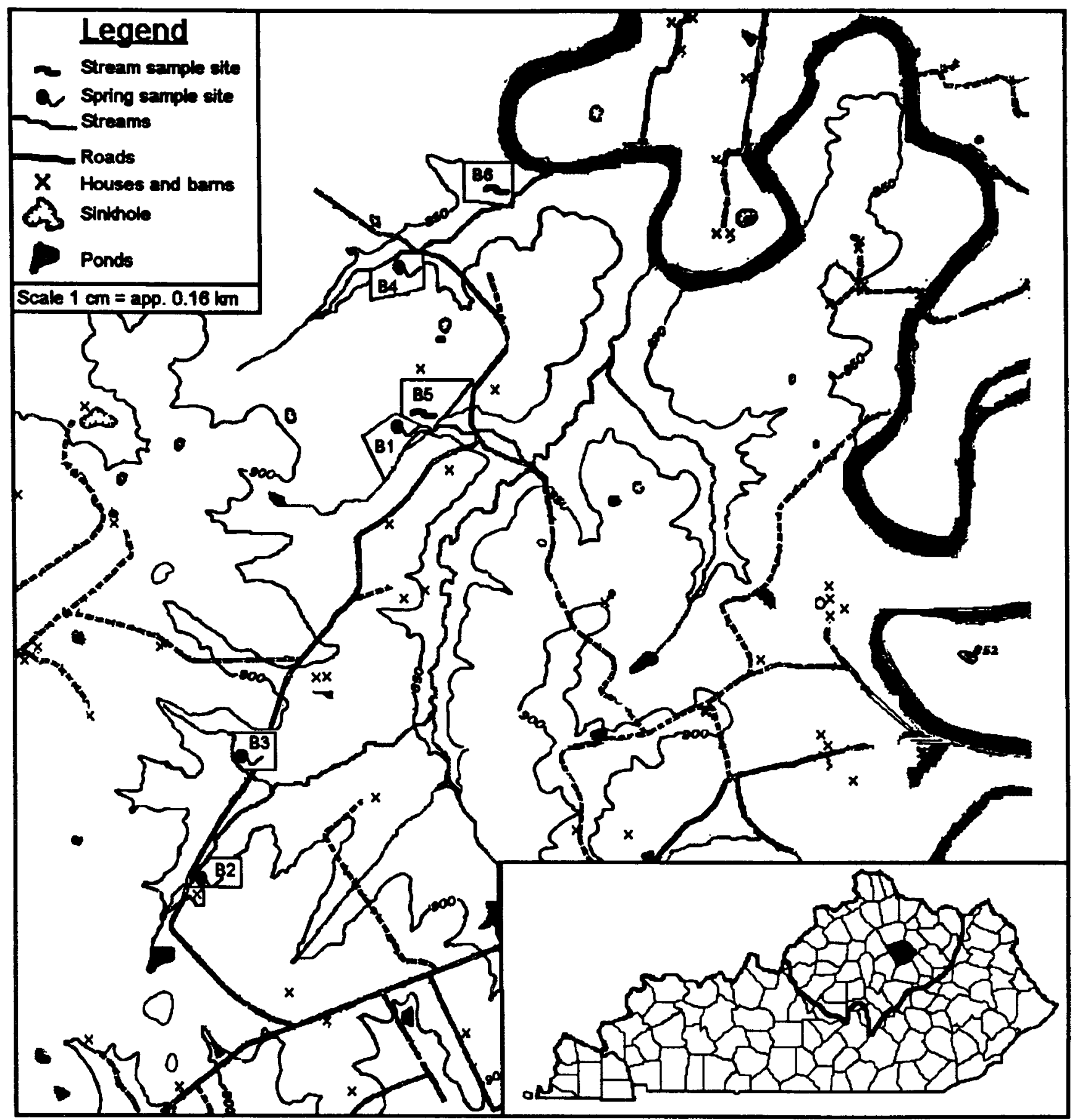

Fig. 1. Location of sampling sites within the Bourbon County watershed.

\section{MATERIALS AND METHODS}

Sites were sampled on Tuesday, a predetermined day, to avoid sampler bias due to inclement weather (Thomas et al., 1992). Sites were sampled weekly, when possible, from January 1992 to July 1992 and monthly from July 1992 to January 1993. Spring and stream water samples were taken by hand using sterile plastic bags. A sterile plastic bottle taped to a golf ball retriever was used to sample well water. Well water was then transferred to a sterile plastic bag. A total of 302 samples were taken and analyzed throughout the study.

Five hundred-milliliter water samples were collected, stored on ice, and plated on selective media within $24 \mathrm{~h}$. Fecal coliforms and fecal streptococci were enumerated by membrane filtration utilizing sterile gridded cellulose filters with a $0.45-$ micron nominal pore size (Micron Separations, Westboro, MA) (APHA, 1992). Replicate filters were made from each water sample. The appropriate sample volume was estimated by observing the cattle loading rate and previous precipitation pattern for each sample site and date. Fecal streptococci were incubated on Kenner Fecal Streptococcus (KFS) agar (Difco Corp., Detroit, MI) for $44 \pm 4 \mathrm{~h}$ at $35^{\circ} \mathrm{C}$ in an incubator. Fecal coliform were incubated on $\mathrm{M}$ Fecal Coliform (MFC) agar (Difco) for $22 \pm 2 \mathrm{~h}$ at $44.5^{\circ} \mathrm{C}$ in a constant temperature water bath. 
Table 1. Land use for Bourbon and Fleming County sampling sites.

\begin{tabular}{|c|c|c|}
\hline $\begin{array}{l}\text { Sampling } \\
\text { site }\end{array}$ & $\begin{array}{l}\text { Water } \\
\text { source }\end{array}$ & Major land use in 1992 \\
\hline $\begin{array}{l}\text { Bourbon C } \\
\text { B1 } \\
\text { B2 } \\
\text { B3 } \\
\text { B4 } \\
\text { B5 } \\
\text { B6 }\end{array}$ & $\begin{array}{l}\text { Spring } \\
\text { Spring } \\
\text { Spring } \\
\text { Spring } \\
\text { Stream } \\
\text { Stream }\end{array}$ & $\begin{array}{l}\text { Pasture, hay, corn, soybean, and beef cattle } \\
\text { Hay, alfalfa, and a house } \\
\text { Pasture, hay, corn, and beef cattle } \\
\text { Pasture, hay, corn, soybean, and beef cattle } \\
\text { Pasture, hay, corn, soybean, and beef cattle } \\
\text { Pasture, hay, corn, soybean, and beef cattle }\end{array}$ \\
\hline $\begin{array}{l}\text { Fleming C } \\
\text { F1 } \\
\text { F2 } \\
\text { F3 } \\
\text { F4 } \\
\text { F5 }\end{array}$ & $\begin{array}{l}\text { Spring } \\
\text { Spring } \\
\text { Stream } \\
\text { Well } \\
\text { Well }\end{array}$ & $\begin{array}{l}\text { Pasture, hay, beef and dairy cattle } \\
\text { Pasture, hay, beef and dairy cattle } \\
\text { Pasture, hay, feed lot, and dairy cattle } \\
\text { Pasture, hay, dairy parlor/feed lot, and house } \\
\text { Pasture, hay, feed lot, and dairy cattle }\end{array}$ \\
\hline
\end{tabular}

Several criteria are needed for an accurate source identification by the FC/FS ratio: stream travel time of $<24 \mathrm{~h},>100$ fecal streptococci/100 mL, and sample pH between 4 and 9 (Geldreich, 1976). The FC/FS ratio data we report in this study meet these criteria.

Early in the study, presumptive fecal coliform were tested for glucuronidase activity and for positive identification of Escherichia coli (Rice et al., 1991) to ensure the accuracy of the fecal coliform enumeration. Colonies of varying size, shape, and color from MFC agar plates were inoculated into broth containing 4-methylumbelliferyl $\beta$-D glucuronide (MUG), which indicates glucuronidase activity, when the fluorescent product 4-methylumbelliferyl is released. The number of false negative ( $\left.\mathrm{MUG}^{-}\right)$E. coli in environmental samples from similar locations is $<2.5 \%$ (Coyne and Shuler, 1994). Only characteristic colonies that invariably had glucuronidase activity were counted throughout the study.

Water temperatures were measured by a Fluke $51 \mathrm{~K} / \mathrm{J}$ thermometer. Precipitation data was obtained from the National Climatic Data Center's Climatological Data Annual Summary, which provided rainfall data for both counties (NOAA, 1992). The data presented are the sum of precipitation for the $2 \mathrm{~d}$ preceding sampling and the sample day.

Statistical comparisons and LSMeans were determined on the Statistical Analysis System (SAS Inst., 1992) using the Mixed procedure. We used Toeplitz and Exponential covariance structures with Log Likelihood Ratio tests to find a suitable model for the variance-covariance structure of the residual errors before LSMeans and contrasts were done.

Data were analyzed by SAS procedure Mixed using the model $y_{\mathrm{ij}}=\mu+s_{\mathrm{i}}+d_{\mathrm{j}}+e_{\mathrm{ij}}$ where $\mu$ is the overall mean, $s_{i}$ the effect of the $i$ th site (considered fixed), $d_{j}$ the effect of the $j$ th day (considered random), and $e_{i j}$ a residual error. Preliminary investigation of the variance-covariance structure of the residual errors indicated that observations within a site that were close together in time were highly correlated, but the correlation became less as the time between observations increased. The Exponential covariance structure was used in the final analysis to compute LSMeans and tests of contrasts.

\section{RESULTS AND DISCUSSION \\ Extent and Pattern of Fecal Contamination}

Water quality standards were frequently exceeded by nonpoint source fecal contamination. Mean fecal coliform concentrations exceeded primary contact standards for all sites and in 7 of 11 sites more than $50 \%$ of the samples exceeded primary contact water standards (Table 2).

\section{Wells}

Well F5 had significantly more fecal coliforms $(P=$ $0.043)$ and exceeded primary contact water standards more frequently than Well F4 $(P=0.002)$ (Table 2). Well F5 was located below a feedlot and $3 \mathrm{~m}$ from Stream F3. Fecal contamination in the well may have been due to bacterial influx from Stream F3, which was contaminated by fecal coliform throughout the study (Table 2). Rahe et al. (1978) found that $E$. coli were transported $30 \mathrm{~m}$ laterally through soil from injection wells. Hagedorn et al. (1978) found that fecal bacteria transport through soil was maximal during the rise of the water table following rain.

Well F5 may also frequently exceed primary contact standards because of its construction and depth. Well F4 is 8 to $9 \mathrm{~m}$ deep and lined with concrete, but Well F5 is only 3 to $4.5 \mathrm{~m}$ deep and lined with creek rock. Ilvento et al. (1994) found that poorly constructed shallow wells are more likely to exceed maximum contaminant levels than properly constructed deeper wells.

\section{Springs}

Springs frequently exceeded primary contact water standards, but there were periods when fecal coliform were not detectable (Table 2). In two springs in Fleming County (F1 and F2) that were in the same pasture but physically separated, only $29 \%$ of the samples exceeded primary contact standards before cattle were present. After cattle began grazing the surrounding pasture, $80 \%$ of the samples exceeded primary contact standards. As long as cattle remained on site, from March through December, fecal coliform concentrations rose above average precattle levels with each rainfall event (Fig. 3). Due to low rainfall from July 1992 until October 1992, Springs F1 and F2 contained fewer than 400 fecal coliforms $/ 100 \mathrm{~mL}$ and were periodically dry.

Fecal coliform concentrations in springs were not significantly different between counties $(P=0.302)$, but primary contact standards were exceeded more often by Fleming County springs than Bourbon County springs $(P=$ 0.004 ) (Table 2). This was probably due to differences in cattle management. At the Bourbon County site, pastures were grazed sporadically while the pasture surrounding Springs F1 and F2 in Fleming County was continuously grazed from March 1992 until January 1993.

Another reason Fleming County springs exceeded primary contact standards more frequently than Bourbon County springs could be because the soils are shallower. Deeper soils may trap more fecal bacteria than shallow soils. Maury and Lowell silt loams, with soil depth to bedrock ranging from 102 to $305 \mathrm{~cm}$, are the dominant soils surrounding the Bourbon County springs. The Fleming County Springs F1 and F2 are dominantly overlain by a Cynthiana silty clay loam with a depth to bedrock of between 25 to $51 \mathrm{~cm}$.

For springs and wells (groundwater) to regularly exceed primary contact standards for fecal coliform, bacteria must be transported through soil. Macropore transport of water and solutes bypasses the soil matrix in well structured soils (Thomas and Phillips, 1979). Bacteria 


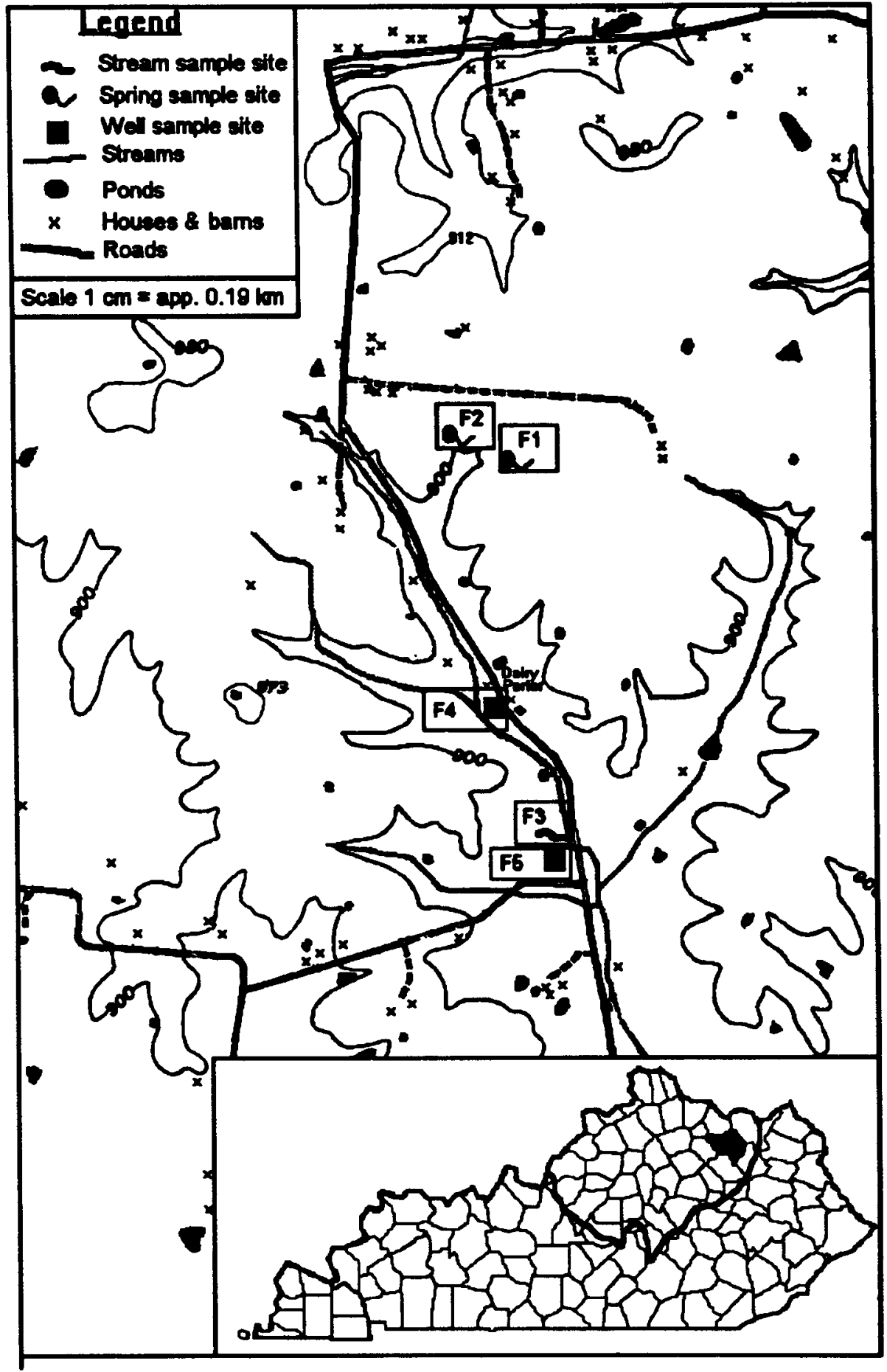

Fig. 2. Location of sampling sites within the Fleming County watershed.

may also bypass the filtering affects of the soil matrix if pores are large enough. Smith et al. (1985) showed that rapid fecal bacteria movement occurs through intact soil columns.

A source of fecal bacteria, along with a driving force like rainfall, must be present to move fecal bacteria through soil into a spring or well. Although fecal bacteria persist in manure deposits (Thelin and Gifford, 1983), springs and wells are protected until there is a rain that moves the bacteria through soil.

\section{Streams}

Fecal coliforms were always present in streams, and almost always exceeded primary contact water standards. Streams also had the highest mean fecal coliform concentrations (Table 2).

Fecal coliform concentrations increased in streams after rainfall and when cattle were present. Unlike springs, high fecal coliform concentrations were observed in the absence of either rain or cattle. Several 
Table 2. Minimum, mean, and maximum fecal coliform concentrations (fecal coliforms $/ 100 \mathrm{~mL}$ ) and the percent of samples exceeding USEPA primary contact water standards ( 200 fecal coliforms $/ 100 \mathrm{~mL}$ ) for springs, streams, and wells in Bourbon and Fleming Counties.

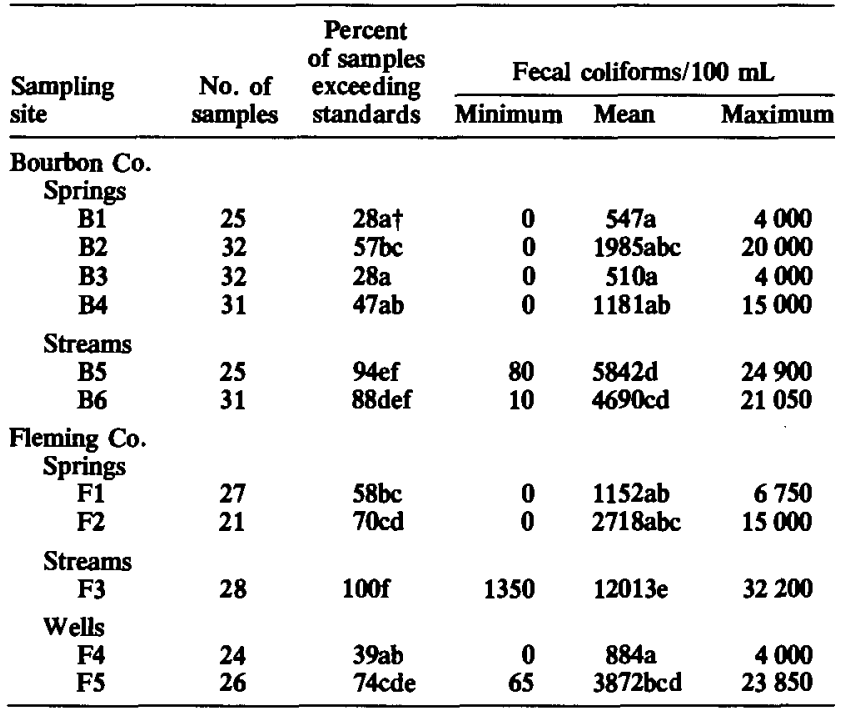

$\dagger$ Percents and means with the same letter are not different at $a=0.05$.

studies have documented fecal coliform survival and regrowth in stream sediments (Sherer et al., 1988, 1992; Stephenson and Rychert, 1982). Sherer et al. (1988) found that fecal bacteria in sediments could be resuspended after stream bottom disturbance.

At Bourbon County Streams B5 and B6, we observed the effect of cattle presence and absence on fecal coliform concentrations (Fig. 4). Cattle were rotated on and off the pastures surrounding Streams B5 and B6. Fecal coliform concentrations in both streams were quite variable. Cattle grazed the area surrounding Stream B5 from December 1991 to April 1992. When they were present, the fecal coliform concentration remained $>200$ fecal coliforms/
Table 3. Mean fecal coliform concentrations (CFU/100 $\mathrm{mL}$, colony forming unit) and the percent of samples exceeding primary contact water standards estimated by monthly and weekly sampling for each site.

\begin{tabular}{|c|c|c|c|c|}
\hline \multirow[b]{2}{*}{$\begin{array}{l}\text { Sampling } \\
\text { site }\end{array}$} & \multicolumn{2}{|c|}{$\begin{array}{l}\text { Mean fecal } \\
\text { coliform conc. }\end{array}$} & \multicolumn{2}{|c|}{$\begin{array}{l}\text { Percent of samples } \\
\text { exceeding standards }\end{array}$} \\
\hline & $\begin{array}{l}\text { Monthly } \\
\text { sampling }\end{array}$ & $\begin{array}{l}\text { Weekly } \\
\text { sampling }\end{array}$ & $\begin{array}{l}\text { Monthly } \\
\text { sampling }\end{array}$ & $\begin{array}{c}\text { Weekly } \\
\text { sampling }\end{array}$ \\
\hline \multicolumn{5}{|c|}{$\begin{array}{l}\text { Bourbon Co. } \\
\text { Springs }\end{array}$} \\
\hline $\begin{array}{l}\text { B1 } \\
\text { B2 } \\
\text { B3 } \\
\text { B4 }\end{array}$ & $\begin{array}{r}509 \\
910 \\
344 \\
2484\end{array}$ & $\begin{array}{r}427 \\
847 \\
579 \\
1636\end{array}$ & $\begin{array}{l}20 \\
87 \\
43 \\
71\end{array}$ & $\begin{array}{l}27 \\
66 \\
43 \\
51\end{array}$ \\
\hline $\begin{array}{c}\text { Streams } \\
\text { B5 } \\
\text { B6 }\end{array}$ & $\begin{array}{c}8882 \\
10422^{* *}\end{array}$ & $\begin{array}{l}8475 \\
7039 * *\end{array}$ & $\begin{array}{r}100 \\
86\end{array}$ & $\begin{array}{r}100 \\
80\end{array}$ \\
\hline \multicolumn{5}{|c|}{$\begin{array}{c}\text { Fleming Co. } \\
\text { Springs }\end{array}$} \\
\hline $\begin{array}{l}\text { F1 } \\
\text { F2 }\end{array}$ & $\begin{array}{l}1227 \\
1757\end{array}$ & $\begin{array}{l}1249 \\
3316\end{array}$ & $\begin{array}{l}85 * * \\
83\end{array}$ & $\begin{array}{l}59 * * \\
77\end{array}$ \\
\hline $\begin{array}{c}\text { Streams } \\
\text { F3 }\end{array}$ & 15277 & 13598 & 100 & 100 \\
\hline $\begin{array}{r}\text { Wells } \\
\text { F4 } \\
\text { F5 }\end{array}$ & $\begin{array}{l}1519 \\
8160^{* *}\end{array}$ & $\begin{array}{l}1225 \\
5663^{* *}\end{array}$ & $\begin{array}{l}63 \\
71\end{array}$ & $\begin{array}{l}49 \\
72\end{array}$ \\
\hline
\end{tabular}

$100 \mathrm{~mL}$, the primary contact standard, and fluctuated between a minimum of 380 fecal coliforms $/ 100 \mathrm{~mL}$ and a maximum of 20000 fecal coliforms $/ 100 \mathrm{~mL}$. Four weeks after cattle were removed from Site B5, the fecal coliform population reached its maximum of 24900 fecal coliforms $/ 100 \mathrm{~mL}$ and remained elevated through May.

While cattle were absent from the pasture surrounding Stream B6 from the second sampling date in January until March, fecal coliform concentrations remained $<250 / 100 \mathrm{~mL}$. While cattle were grazing the pasture, from the last sampling date in March until the second sample date in April and again on the first sample date

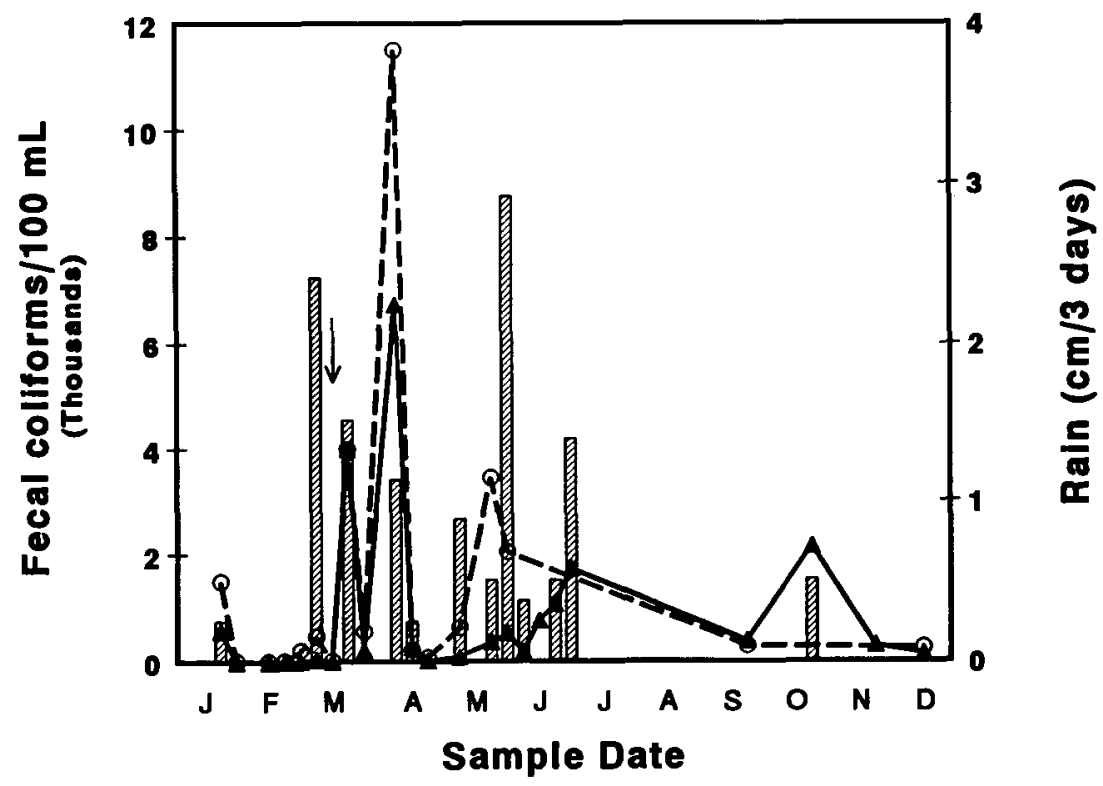

Fig. 3. Fecal coliform concentrations in Fleming County Springs F1 $(\Delta)$ and $F 2(O)$ as influenced by rainfall and cattle presence. Lined bars represent rainfall $(\mathrm{cm} / 3 \mathrm{~d})$. Cattle were present after the date indicated by the arrow. 
in May, fecal coliform concentrations remained $>10000$ / $100 \mathrm{~mL}$. After cattle removal in May, fecal coliform concentrations remained $>15000 / 100 \mathrm{~mL}$ throughout the month.

The high fecal coliform populations in Streams B5 and B6 after cattle removal were probably due to the warmer temperatures with the onset of spring. Jawson et al. (1982) concluded from a 3-yr study that, after the warmer weather of spring, fecal coliform numbers in runoff increased long after cattle had been removed.

Low fecal coliform concentrations in Streams B5 and B6 from August to December were associated with the absence of cattle from June to December on both sites. Even with a large rainfall event before the November sampling, fecal coliform concentrations in Stream B6 was low compared with concentrations before cattle were removed.

Stream F3 received runoff from a dairy parlor and feedlot, a point source of contamination. Beginning in March, fecal coliform concentrations rose above 7000/ $100 \mathrm{~mL}$ and remained elevated until June (Fig. 5). Significantly higher fecal coliform concentrations $(P=$ 0.001 ) were in Fleming County Stream F3 than in Bourbon County Streams B5 and B6. However, while the latter sites are typical of nonpoint sources of water pollution, they exceeded primary contact water standards statistically the same as Stream F3 $(P=0.239)$ and had greater fluctuation in fecal coliform concentration. These data indicate that, in some cases, nonpoint sources of pollution can adversely impact agricultural waters much like point sources. They also indicate that testing compliance with a set standard may not indicate the severity of contamination.

\section{Sampling Frequency}

Fecal bacteria are monitored in natural waters to obtain information about pollution and for testing compliance with bacteriological standards (Niemi and Niemi, 1990).

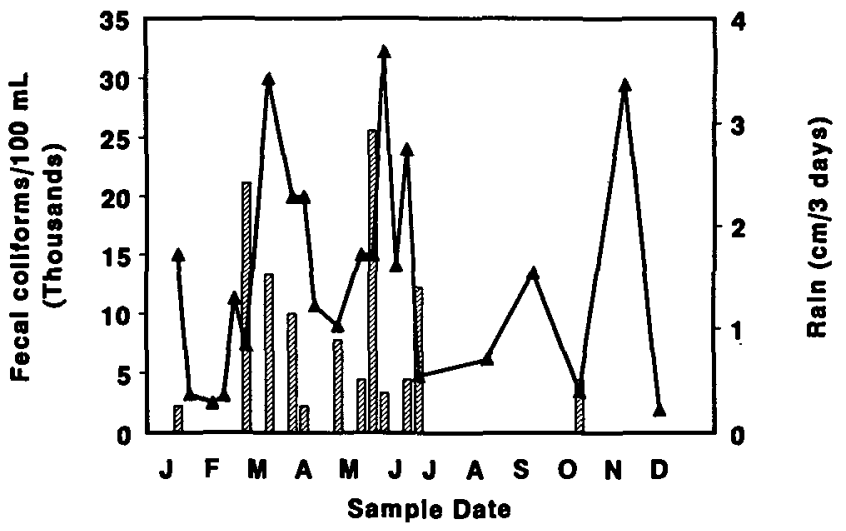

Fig. 5. Fecal coliform concentrations in Fleming County Stream F3 $(\Delta)$ as inftuenced by a point source of fecal bacteria. Lined bars represent rainfall $(\mathrm{cm} / 3 \mathrm{~d})$.

The proper sampling frequency must be used to obtain an unbiased reliable water quality assessment of a site (Cotter, 1985). To compare the reliability of monthly sampling to weekly sampling, we determined the expected variance of least squares means for monthly sampling under the estimated variance-covariance structure of the complete data from the period January 1992 to June 1992. To determine if monthly sampling resulted in any consistent bias in estimated means, monthly sampling means were contrasted with weekly sampling means for complimentary sampling dates within each site and were tested for statistical significance.

Monthly sampling means for Stream B6 and Well F5 were significantly different $(\alpha=0.05)$ from weekly sampling means (Table 3). The percent of time samples exceeded primary contact standards for monthly sampling was significantly different $(\alpha=0.05)$ from weekly sampling only at Spring F1. Sampling frequency made a difference at individual sites, but there was no significant difference between monthly and weekly sampling means within sites $(P=0.414)$, nor was the percent of time

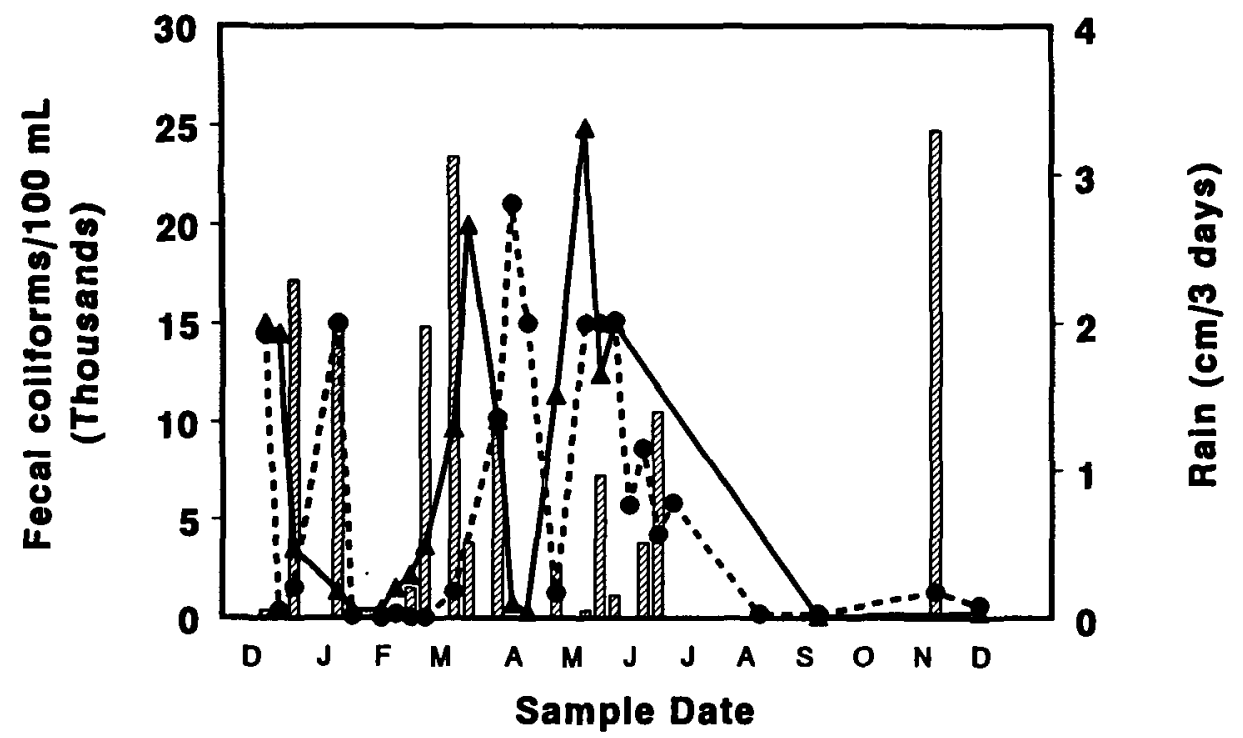

Fig. 4. Fecal coliform concentrations in Bourbon County Streams B5 $(\Delta)$ and B6 $(\Theta)$ as influenced by rainfall and cattle presence. Lined bars represent rainfall $(\mathrm{cm} / 3 \mathrm{~d})$. 
samples exceeded the primary contact standard for monthly and weekly sampling significantly different within sites $(P=0.299)$. These results indicate that little bias was introduced by monthly sampling at these sites.

Since cattle were present on most sites at least once a month, fecal coliforms were always present. With this type of management, monthly sampling adequately reflected fecal contamination of water. If cattle grazing were only periodic, or short term, monthly sampling might not accurately reflect fecal coliform concentrations associated with grazing patterns and could result in an inaccurate water quality assessment.

Monthly sampling may be sufficient for a general watershed assessment. More frequent sampling may be required to characterize population dynamics and the factors that affect it. Sampling storm events would efficiently identify maximum concentration fluxes at a site.

\section{Fecal Coliform/Fecal Streptococci Ratio}

We chose FC/FS ratios of $<0.1$ for wild animal and $>4.0$ for human sources of contamination. Doran and Linn (1979) suggested that FC/FS ratios between 0.7 and 4.0 could indicate cattle in close proximity to a sampling site. Since cattle were close to our sampling sites, we selected a FC/FS ratio of 0.1 to 4.0 to indicate domestic animal contamination.

The mean FC/FS ratio indicated potential human contamination at every site; that was unlikely (data not shown). When we evaluated the frequency of FC/FS ratios typical of different contamination sources, the indicated source of contamination was consistent with land use at each site. It was not a definitive indicator, as Doran and Linn (1979) and Jawson et al. (1982) suggested.

Figure 6 shows the percent of samples in each site with FC/FS ratios indicating a specific contamination source. Most samples from Fleming and Bourbon County springs had FC/FS ratios indicating domestic animal contamination. Spring B2 potentially received leachate from the septic field of a house located above it. Twentytwo percent of the samples from Spring B2 indicated human contamination. These occurred shortly after the vacant house was reoccupied.

The obvious source of contamination in Wells F4 and F5 was dairy cattle. Twenty-four percent of the samples from Well F5 pointed to human contamination, but it may have been influenced by lateral flow from Stream $\mathrm{F} 3$, which had $\mathrm{FC} / \mathrm{FS}$ ratios exceeding 4.0 approximately $40 \%$ of the time.

All streams frequently had FC/FS ratios indicative of human contamination. This was only likely in Stream F3 where the sampling site was downstream from a house. Seventy-seven and $63 \%$ of the samples in Streams B5 and B6, respectively, were representative of the land use-domestic cattle grazing.

The FC/FS ratio for Streams B5 and B6 increased as temperatures increased during spring (data not shown). Von Donsel (1967) suggested that fecal coliforms survived better than fecal streptococci in summer and fall. Greater growth and increased survival of fecal coliforms in stream sediments compared with fecal streptococci may also have elevated FC/FS ratios (Sherer et al., 1989, 1992; Stephenson and Rychert, 1982).

\section{CONCLUSIONS}

The fecal bacteria populations in shallow groundwater and streamflow from these agricultural watersheds are characteristic of nonpoint-source pollution in rural areas. All sites frequently exceeded primary contact water quality standards; some greatly exceeded the standard. Since these study sites represent land use and management systems typical of central Kentucky, it is probable that current water quality standards for shallow water sources are frequently exceeded in this region.

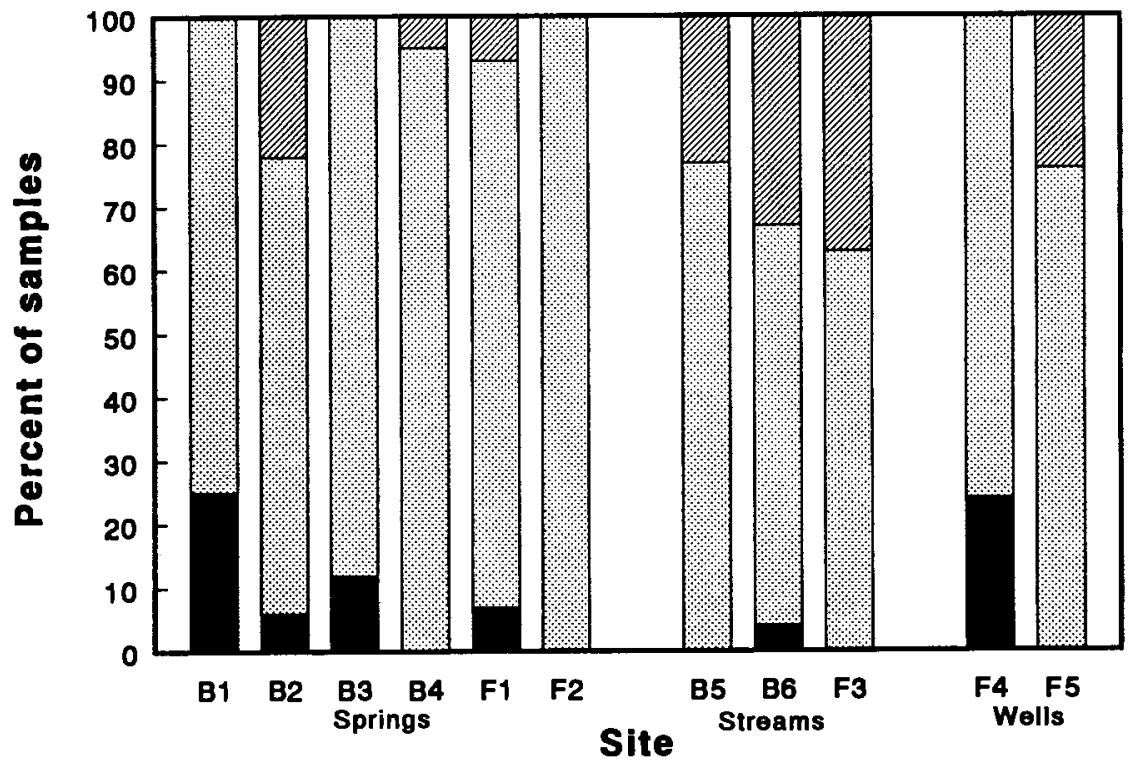

Fig. 6. Percent of samples from each site with FC/FS ratios indicating specific contamination sources. The solid bars represent samples with a ratio of $<0.1$, indicating wildlife contamination; the dotted bars represent samples with a ratio between 0.1 and 4.0 , indicating domestic animal contamination; and the lined bars represent samples with a ratio $>\mathbf{4 . 0}$, indicating human contamination. 
In Bourbon County, pastures were intensively grazed and then fallowed. Consequently, fewer samples exceeded primary contact standards in Bourbon County springs than in Fleming County where pastures were continuously grazed. Different cattle management could conceivably reduce fecal coliform concentrations and make current water quality standards obtainable in agricultural runoff, although it is questionable whether current water quality standards are applicable to agricultural runoff when fecal indicator bacteria are used as the principle criterion of water quality.

Our results indicate that groundwater contamination can occur when a source of fecal bacteria is present. However, a driving force like rainfall is required to elevate fecal coliform concentrations in springs and wells. Once deposition occurs in streams, increased survival and regrowth of fecal coliform in stream sediments, with subsequent resuspension, may elevate fecal coliform concentrations in the absence of cattle and rainfall.

In these management settings, monthly sampling adequately reflected fecal contamination and the FC/FS ratio appeared to distinguish between wild and domestic animal contamination of water. However, the FC/FS ratio could not be used to unambiguously distinguish between domestic animal and human sources of fecal contamination for a variety of reasons. The FC/FS ratio's use as a regulatory rather than a diagnostic tool to identify contamination sources would be questionable.

\section{ACKNOWLEDGMENTS}

We thank Grant Thomas and Gerald Haszler, University of Kentucky, for identifying the study sites, and for relevant soil, geological, and land use information. This work was supported by a grant from the State of Kentucky Senate Bill 271 Water Quality Research Program.

\section{REFERENCES}

American Public Health Association. 1992. Standard methods for the analysis of water and wastewater. 18th ed. APHA, Washington, DC.

Cotter, A.J.R. 1985. Water quality surveys: A statistical method based on determinism, quantiles and the bionomial distribution. Water Res. 19:1179-1189.

Coyne, M.S., and J. Shuler. 1994. Frequency of MUG negative Escherichia coli in Kentucky groundwater samples. J. Environ. Qual. 23:126-129.

Davis, E.M., D.M. Casserly, and J.D. Moore. 1977. Bacterial relationships in stormwaters. Water Resour. Bull. 13:895-905.

Dixon, J.E., G.R. Stephenson, A.J. Lingg, and D.D. Hinman. 1977. Nonpoint pollution control for wintering range cattle. ASAE Pap. 77-4049. ASAE, St. Joseph, MI.

Doran, J.E., and D.M. Linn. 1979. Bacteriological quality of runoff water from pastureland. Appl. Environ. Microbiol. 37:985-991.

Gary, H.L., S.R. Johnson, and S.L Ponce. 1983. Cattle grazing impact on surface water quality in a Colorado Front Range stream. J. Soil Water Conserv. 38:124-128.

Geldreich, E.E. 1976. Fecal coliform and fecal streptococcus density relationships in waste discharges and receiving waters. Crit. Rev. Environ. Control 6:349-369.

Hagedorn, C., D.T. Hansen, and G.H. Simonson. 1978. Survival and movement of fecal indicator bacteria in soil under conditions of saturated flow. J. Environ. Qual. 7:55-59.

Ilvento, T., L. Heaton, and J. Taraba. 1992. Understanding the water system. Kentucky Coop. Ext. Service Bull. IP-1. Kentucky Agric. Exp. Stn., Lexington, KY.

Ilvento, T., J. Taraba, K. Henken, and J. Dinger. 1994. Groundwater education and well water testing program, summary of results. Spec. Rep. Kentucky Coop. Ext. Service. Kentucky Agric. Exp. Stn., Lexington, $\mathrm{KY}$.

Jacobs, S.E. 1994. Soil survey of Fleming county, Kentucky. USDA$\mathrm{SCS}$, Lexington, $\mathrm{KY}$.

Jawson, M.D., L.F. Elliott, K.E. Saxton, and D.H. Fortier. 1982. The effect of cattle grazing on indicator bacteria in runoff from a Pacific Northwest watershed. J. Environ. Qual. 11:621-627.

Kunkle, S.H. 1970. Concentrations and cycles of bacteria indicators in farm surface runoff. p. 49-60. In Relationship of agriculture to soil and water pollution. Cornell Univ. Conf. on Agricultural Waste Management, Ithaca, NY. 19-21 Jan. 1970. Cornell Univ., Ithaca, NY.

National Oceanic and Atmospheric Administration. 1992. Climatological data: Kentucky. Vol. 87. NOAA, Ashville, NC.

Niemi, R.M., and J.S. Niemi. 1990. Monitoring of fecal indicators in rivers on the basis of random sampling and percentiles. Water Air Soil Pollut. 50:331-342.

Niemi, R.M., and J.S. Niemi. 1991. Bacterial pollution of waters in pristine and agricultural lands. J. Environ. Qual. 20:620-627.

Rahe, T.M., C. Hagedorn, E.L. McCoy, and G.F. Kling. 1978. Transport of antibiotic-resistant Escherichia coli through western Oregon hillslope soils under conditions of saturated flow. J. Environ. Qual. 7:487-494.

Rice, E.W., M.J. Allen, D.J. Brenner, and S.C. Edberg. 1991. Assay for B-glucuronidase in species of the genus Escherichia and its applications for drinking water analysis. Appl. Environ. Microbiol. 57:592-593.

Richardson, A.J., R. Forsythe, and H.B. Odor. 1982. Soil survey of Bourbon and Nicholas counties, Kentucky. USDA-SCS, Lexington, KY.

Sherer, B.M., J.R. Miner, J.A. Moore, and J.C. Buckhouse. 1988. Resuspending organisms from a rangeland stream bottom. Trans. ASAE 31:1217-1222.

Sherer, B.M., J.R. Miner, J.A. Moore, and J.C. Buckhouse. 1992. Indicator bacterial survival in stream sediments. J. Environ. Qual. 21:591-595.

Smith, M.S., G.W. Thomas, R.E. White, and D. Ritonga. 1985. Transport of Escherichia coli through intact and disturbed soil columns. J. Environ. Qual. 14:87-91.

Statistical Analysis System. 1992. SAS/STAT software: Changes and enhancements. Release 6.07. SAS Tech. Rep. SAS Inst., Cary, NC.

Stephenson, G.R., and R.C. Rychert. 1982. Bottom sediment: A reservoir of Escherichia coli in rangeland streams. J. Range Manage. $35: 119-123$.

Stephenson, G.R., and L.U. Street. 1978. Bacterial variations in streams from a southwest Idaho rangeland watershed. J. Environ. Qual. 7:150-157.

Thelin, R., and G.F. Gifford. 1983. Fecal coliform release patterns from fecal material of cattle. J. Environ. Qual. 12:57-63.

Thomas, G.W., G.R. Hazler, and J.M. Howell. 1992. Sampling frequency and sampler bias effects on water quality parameters. p. 61. In Agronomy abstracts. ASA, Madison, WI.

Thomas, G.W., and R.E. Phillips. 1979. Consequences of water movement in macropores. J. Environ. Qual. 8:149-152.

Tiedemann, A.R., D.A. Higgins, T.M. Quigley, H.R. Sanderson, and C.C. Bohn. 1988. Bacterial water quality responses to four grazing strategies - comparisons with Oregon Standards. J. Environ. Qual. 17:492-498.

Von Donsel, D.J., E.E. Geldreich, and N.A. Clarke. 1967. Seasonal variations in survival of indicator bacteria in soil and their contribution to storm-water pollution. Appl. Microbiol. 15:1362-1370. 